NBER WORKING PAPER SERIES

\title{
EXPORTING AND PRODUCTIVITY
}

Andrew B. Bernard

J. Bradford Jensen

Working Paper 7135

http://www.nber.org/papers/w7135

\author{
NATIONAL BUREAU OF ECONOMIC RESEARCH \\ 1050 Massachusetts Avenue \\ Cambridge, MA 02138 \\ May 1999
}

We are grateful to seminar participants at the NBER, Dartmouth, Harvard, NYU, Toronto, Yale, the IMF, the World Bank, and the EIIT conference for helpful comments. Financial support from Bernard's research by the Frederick Frank Fund for International Research is gratefully acknowledged. All errors are our own. The views expressed herein are those of the authors and do not necessarily reflect the views of the National Bureau of Economic Research.

(C) 1999 by Andrew B. Bernard and J. Bradford Jensen. All rights reserved. Short sections of text, not to exceed two paragraphs, may be quoted without explicit permission provided that full credit, including $(\mathbb{C}$ notice, is given to the source. 
Exporting and Productivity

Andrew B. Bernard and J. Bradford Jensen

NBER Working Paper No. 7135

May 1999

JEL No. F10, F43, O47

\begin{abstract}
Exporting is often touted as a way to increase economic growth. This paper examines whether exporting has played any role in increasing productivity growth in U.S. manufacturing. Contemporaneous levels of exports and productivity are indeed positively correlated across manufacturing industries. However, tests on industry data show causality from productivity to exporting but not the reverse. While exporting plants have substantially higher productivity levels, we find no evidence that exporting increases plant productivity growth rates. However, within the same industry, exporters do grow faster than non-exporters in terms of both shipments and employment. We show that exporting is associated with the reallocation of resources from less efficient to more efficient plants. In the aggregate, these reallocation effects are quite large, making up over $40 \%$ of total factor productivity growth in the manufacturing sector. Half of this reallocation to more productive plants occurs within industries and the direction of the reallocation is towards exporting plants. The positive contribution of exporters even shows up in import-competing industries and non-tradable sectors. The overall contribution of exporters to manufacturing productivity growth far exceeds their shares of employment and output.
\end{abstract}

Andrew B. Bernard

Yale School of Management

135 Prospect St.

PO Box 208200

New Haven, CT 06520-8200

and NBER

andrew.bernard@yale.edu
J. Bradford Jensen

H. John Heinz III School of Public Policy and Management

Carnegie Mellon University

Pittsburgh, PA 15213 


\section{Introduction}

Recent years have seen a resurgence in interest in the role of international openness and international trade in economic growth. At the same time, a debate has raged over the relative importance of trade and technology in determining the standard of living for workers in developed countries. While the role of trade in promoting economic well-being has a long tradition in the trade literature, the interaction between international trade and long run output and productivity movements is less well understood. In this paper, we ask whether growing trade, in the form of exports, leads to faster productivity and output growth, or whether productivity growth increases exporting. We provide the first direct evidence based on microeconomic data of how trade might be related to aggregate total factor productivity growth rates.

Figures 1 and 2 present two versions of the relationships we would like to disentangle. Shown in Figure 1 are annual log labor productivity levels and the $\log$ levels of real exports for 4-digit Standard Industrial Classification (SIC) manufacturing sectors for the period 1958-1994 after removing aggregate year effects. ${ }^{1}$ Figure 2 shows annual industry total factor productivity growth rates and annual industry growth rates in real exports for the same period, again with year effects removed. Across U.S. manufacturing industries, both labor productivity levels and TFP growth rates are positively and significantly correlated with measures of industry exports. However, the cross-industry correlations do little to inform us about the structure of any underlying causal relationships.

Our research focuses on the role of exporting, if any, in increasing productivity growth in U.S. manufacturing. We concentrate on the hypothesis that exporting has a causal impact on growth rates of productivity. Recent work in the growth literature has outlined a variety of mechanisms by which increased trade might affect aggregate productivity growth. ${ }^{2} \mathrm{~A}$ major theme in this research agenda has been the possibility that trade facilitates the transfer of knowledge and ideas across countries, e.g. Grossman and Helpman (1991), Ben-David and Loewy (1998) and Feeney (1999). For the most part, these models focus on the possibility that lower productivity countries might catch up to leading countries, but allow no productivity benefits to the leader. Exceptions are Ben-David and Loewy (1998) and Feeney

\footnotetext{
${ }^{1}$ In other words we regress both variables on year dummies before plotting them.

${ }^{2}$ See among others Grossman and Helpman (1991), Rivera-Batiz and Romer (1991), Romer (1994), and Feenstra (1996).
} 
Figure 1: Exports and Labor Productivity Levels in U.S. Manufacturing, 1958-1994 (year effects removed)

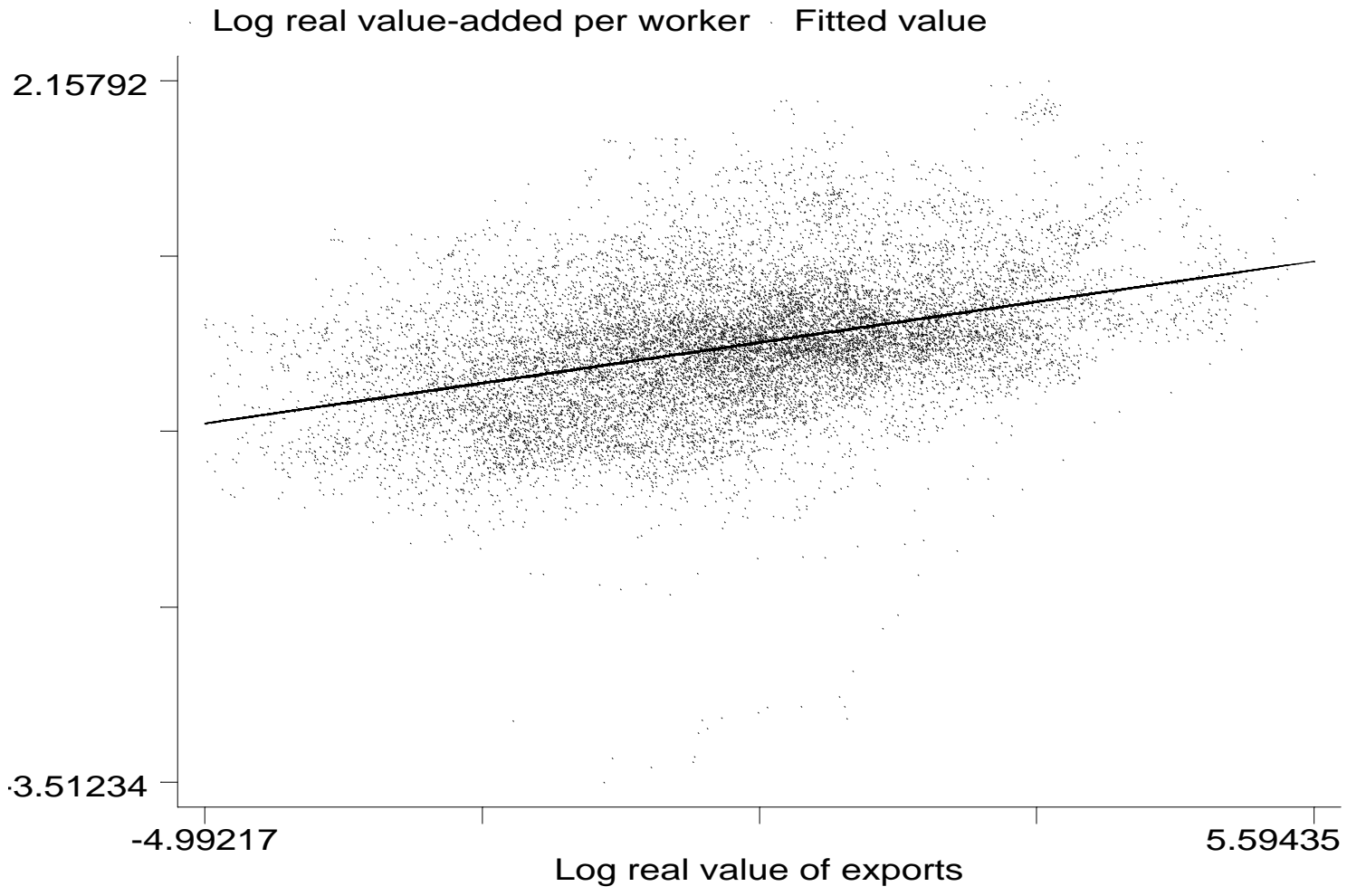

(1999). The former develops a model where openness to trade leads to the incorporation of foreign knowledge in the domestic production function, thus potentially increasing steady state growth. Feeney (1999) considers sectorspecific learning by doing that is enhanced by specialization due to trade. Her model predicts that the exporting sectors will experience faster productivity growth due to increased size and thus increased sectoral learning. By using microeconomic data at the plant and firm level, as well as industry aggregates, we look for any evidence that participation in the export market leads to faster knowledge accumulation and productivity growth.

At the same time, we recognize the possibility that faster productivity growth allows firms, industries and the economy to increase the flow of 
Figure 2: Export Growth and Total Factor Productivity Growth in U.S. Manufacturing, 1958-1994 (year effects removed)

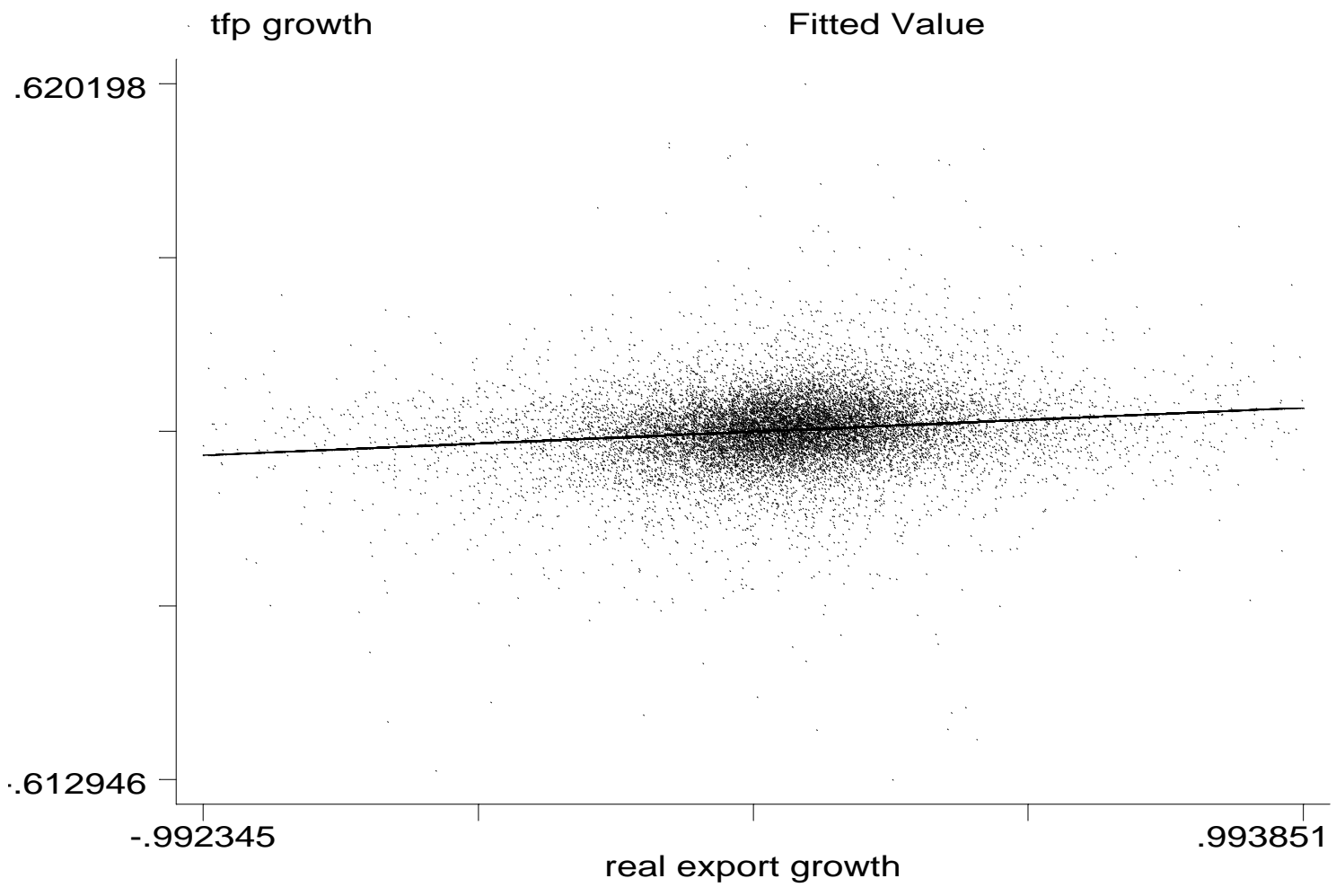

exports. Roberts and Tybout (1997) develop a model of exporting with sunk costs of entry and test it on a sample of Colombian firms. ${ }^{3}$ In the presence of these entry costs, only the relatively productive firms will choose to pay the costs and enter the foreign market. The implied relationship between exporting and productivity is positive in a cross-section of firms or industries, but the causality runs from productivity to exporting. Substantial sunk costs of export entry are not limited to developing countries. Bernard and Jensen (1997) find significant sunk costs for U.S. plants and Bernard and Wagner (1998) get similar results for firms in Germany, a relatively open, developed

\footnotetext{
${ }^{3}$ Clerides, Lach, and Tybout (1998) also find evidence of sunk costs in Morroco and Mexico.
} 
economy.

The relationship between exporting and productivity has important implications for several current areas of research. The debate on the role of international openness in facilitating economic growth has been conducted almost exclusively with aggregate cross-country data. Several recent studies, including Ben-David (1993) and Sachs and Warner (1995), have provided empirical evidence that trade and growth are positively related. Ben-David (1993) shows that members of the EEC had faster output growth rates as trade increased following the removal of trade barriers. Sachs and Warner (1995) conclude that a substantial fraction of the differences in cross-country growth rates over a 30 year period can be correlated with a measure of openness to trade. A recent collection of research on openness and growth, Proudman and Redding eds (1998), conducts both cross-country and crossindustry analyses and strongly concludes that trade facilitates productivity growth. In all this work, the exact mechanism by which openness affects growth is not revealed. ${ }^{4}$ In this paper, we will look at the some of the underlying activity induced by increasing trade. We test whether international trade increases productivity growth within economic units, perhaps by learning or technology transfer, or whether there are any productivity effects at a more aggregate level due to the reallocation of resources across plants or industries.

Our research is also linked to the ongoing debate on trade, technology and wages in the United States. While authors have typically considered either technology or trade ${ }^{5}$ as the primary source of the changing wage distribution in the U.S., we ask to what extent the two are interrelated. We will suggest the appropriate level of disaggregation, if any, to identify separately the effects in the data. This work also relates to a long line of work on the sources of productivity growth and the subsequent effects on firms and industries. We will explore the possibility that within-plant productivity growth is being driven by export behavior.

Finally this paper is a natural extension of the recent work on the microeconomics of trade and exporting. There is substantial accumulated evidence that the act of exporting occurs in firms with very different observable characteristics, even within the same industry. ${ }^{6}$ Exporting plants have

\footnotetext{
${ }^{4}$ See Slaughter (1998) for a discussion of the caveats in interpreting these results as causal.

${ }^{5}$ See Krugman and Lawrence (1993) and Leamer (1996) for two perspectives on the role of trade.

${ }^{6}$ For evidence from other countries, see Bernard and Wagner (1997) on German plants
} 
higher productivity and shipments levels and are more technologically sophisticated than other plants in the same industry (Bernard and Jensen 1995). However, recent work has suggested that exporting confers little or no benefit in the form of faster productivity growth at the plant level (Clerides, Lach, and Tybout 1998, Bernard and Jensen 1999). We extend that work by considering not just the within-plant effects of exporting, but the importance of cross-plant and cross-industry reallocations.

Using plant data, we find little evidence that exporting increases productivity growth rates relative to domestic activity. However, again within the same industry, exporters do grow faster in terms of both domestic and foreign shipments than non-exporters. We confirm that, both within and across industries, exporting is associated with the reallocation of inputs, both labor and capital, from less efficient to more efficient plants. These effects are not predominantly associated with the changing fortunes of different industries. Fully half of this reallocation occurs within industries.

We recognize that our exclusive focus on exports leaves the import part of the trade and productivity relationship unexplored. This is largely because we are constrained by the data; the micro data at the plant and firm level contains no information on imported inputs. The importance of omitting imports is hard to judge. We know from the literature on intra-industry trade that imports and exports tend to move together at the industry level. To the extent that imports and exports have similar effects on productivity, we may mistakenly confound the impact of exports and imports. We avoid this problem in part by working from the plant level to the industry in determining the relationship between exporting and productivity.

If the effects of imports and exports on productivity work in opposite directions, we may actually understate the importance of exports. Indeed the strong, positive correlation between exports and labor productivity levels does not hold for imports, i.e. import and labor productivity levels are only weakly, positively correlated across industries. However, industry TFP growth rates are positively and significantly correlated with contemporaneous growth in real imports.

The paper proceeds as follows: first we document the evidence on the direction of causality between exporting and productivity growth in the aggregate and for 4-digit industries. In Section 3, we present the micro evidence on the productivity-exporting nexus and results on the growth of exporters and non-exporters. In Section 4, we decompose changes in agand Aw and Hwang (1995) for Taiwanese firms. 
gregate productivity in manufacturing into components due to within plant productivity increases and the reallocation of resources across plants and industries. Section 5 concludes.

\section{Trade and Productivity in the Aggregate}

We begin by outlining several mechanisms by which trade might affect aggregate productivity levels. As mentioned above, recent work has concentrated on dynamic effects of trade on growth rates. ${ }^{7}$ In both Ben-David and Loewy (1998) and Feeney (1999), increased trade has the effect of increasing the steady state growth rate of even the leading country, either through increases in the stock of available knowledge or through increased learning-by-doing due to specialization. However, even traditional, static trade models yield predictions about the role of trade in improving productivity. For example, a simple one factor Ricardian model with specialization after opening to trade yields increased welfare for all countries. By assumption there is no role for within-industry productivity increases, but relative price changes increase the real output produced in each country and labor moves towards the industry with comparatively high labor productivity. Throughout the rest of this paper, we look for both within-industry, and within-firm, effects of trade, as well as reallocative effects due to shifting composition of firms within industries, or industries within manufacturing.

\subsection{Data Sources}

The data used in this paper comes from several sources. For micro data on plants, we use the Annual Survey of Manufactures (ASM) from the Longitudinal Research Database (LRD) of the Bureau of the Census. Since we are interested in behavior before and after exporting, we choose our sample to contain the longest currently available period of continuous coverage on exports, 1983-1992. For comparisons involving more than one year we are limited to plants included in the ASM. ${ }^{8}$ This results in an unbalanced panel

\footnotetext{
${ }^{7}$ We restrict our discussion to models that have productivity effects even in the leading country, thus ignoring numerous contributions that discuss transfers from leaders to followers.

${ }^{8}$ The design of the ASM imposes some structure on our analysis. Some plants are included with certainty in each ASM 5 year wave. These 'certainty' cases include all plants with more than 250 employees. Other, generally smaller plants, are included with some probability $(<1)$ in each wave. However, if a non-certainty plant is included in one 5 -year wave it will not be included in the next. See Census (1987) for more information.
} 
with 50-60,000 plants in each year. Due to missing data on capital stocks from 1988-1991 we are forced to construct our own capital stock series from the reported investment series. Appendix A contains a detailed description of the capital stock data.

For the industry level analysis on causality, we combine the BartelsmanBecker-Gray manufacturing industry productivity database from the National Bureau of Economic Research (NBER) with Robert Feenstra's data on imports and exports by 4-digit SIC, also from the NBER. Both databases run from 1958-1994. The aggregate data on labor productivity, imports and exports come from the FRED database of the Federal Reserve Bank of St. Louis. ${ }^{9}$

\subsection{Aggregate growth, productivity, and exporting}

Most work on trade and productivity to date has been conducted using aggregate data. To provide some degree of comparability between our analysis and prior work, we run a simple Granger-causality test on measures of aggregate productivity in the private manufacturing sector and exports. ${ }^{10}$ Using annual data from 1960 through 1996 on real output per hour, multifactor productivity, and log real exports, we estimate two separate VARs with 3 lags each of productivity growth and export growth,

$$
\begin{aligned}
\Delta \ln \operatorname{prod}_{t} & =\sum_{j=1}^{3} \beta_{j}^{1} \Delta \ln \operatorname{prod}_{t-j}+\sum_{j=1}^{3} \alpha_{j}^{1} \Delta \ln \operatorname{export}_{t-j}+\varepsilon_{t}^{1} \\
\Delta \ln _{\text {export }} & =\sum_{j=1}^{3} \beta_{j}^{2} \Delta \ln \operatorname{prod}_{t-j}+\sum_{j=1}^{3} \alpha_{j}^{2} \Delta \ln \operatorname{export}_{t-j}+\varepsilon_{t}^{2} .
\end{aligned}
$$

The sum of the coefficients on export growth in the labor productivity regression is negative in both specifications and significant at the $5 \%$ level in the multifactor productivity specification (see Table 1 ). On the other hand, the sum of the productivity coefficients is positive in both export regressions and significant at the $5 \%$ level for labor productivity. Varying the lag length

\footnotetext{
All industries are classified on a 1972 SIC basis.

${ }^{9}$ All three data sets are available on line: http://www.nber.org/nberprod.html http://www.nber.org/ feenstra/ http://www.stls.frb.org/fred/

${ }^{10}$ Most previous work has focussed on the relationship between GDP growth and export growth, for example Henriques and Sadorsky (1996).
} 
and working with quarterly data did not change the results; exports never showed up as significant in the productivity specification.

One possible problem with such a specification is that it may inappropriately aggregate individual industries with different export experiences. As a check we pool data on individual 4-digit industries from 1958-1994 and rerun our causality tests. The results are given in Table 2 and confirm the aggregate findings. Export growth enters with negative and significant coefficients in the productivity equations, while productivity enters with positive and significant coefficients in the export equations for both productivity measures. ${ }^{11}$

These results suggest that in the aggregate and for individual industries, growth in exports is a result of, and not a source of, increased productivity growth. We now consider the plant level evidence on the exportproductivity relationship.

\section{Exporting, growth and productivity at plants}

To develop our understanding of the relationship between exporting and productivity, we turn to data on individual plants in the manufacturing sector. As with industries, exporting plants have desirable performance characteristics relative to non-exporters, especially labor productivity. Bernard and Jensen (1999) report plant labor productivity differentials 16\%-19\% higher for exporters in the same 4-digit industry. They also report TFP differentials of $13 \%-16 \%$, assuming a common production function within the four digit industry with time-varying coefficients. In this paper, since we are interested in the role of exporting in aggregate productivity growth, we estimate all our specifications with plant-level observations weighted by their sampling probabilities in the LRD.

\subsection{Estimating Plant Productivity}

Throughout the rest of the paper, our productivity measures are derive from plant-level estimates of multi-factor productivity. We start with a model of a profit maximizing firm which faces the same input prices and market structure as other firms within the industry. In addition, production technologies are common to firms within the industry and across years. Individual firms may differ in terms of productive efficiency. Following Ericson and Pakes

\footnotetext{
${ }^{11}$ These results are robust to the inclusion of industry fixed effects.
} 
(1995) and Olley and Pakes (1996), each period the firm first decides to continue operation $(\chi=1)$ or shut down $(\chi=0)$ given its expectations about future productive efficiency and the current capital stock. If it continues, the firm faces choices of the level of variables inputs, such as labor and materials, and investment for future production given the existing capital stock and expectations about its productivity efficiency. Capital is accumulated according to

$$
k_{t+1}=(1-d) k_{t}+i_{t}
$$

Firm productivity consists of two components, $\omega_{t}+\epsilon_{i t}$. $\omega_{t}$ is assumed to be known to the firm at date $t$ (but unknown to the econometrician) and is first order Markov, while $\epsilon_{i t}$ is unknown both to the firm and the econometrician. We will assume that the known productivity process is exogenous to the firm.

The exit rule for the firm is given by

$$
\begin{gathered}
\chi_{t}=1 \text { if } \omega_{t} \geq \underline{\omega}\left(a_{t}, k_{t}\right) \\
0 \text { otherwise }
\end{gathered}
$$

so the firm remains in existence if productivity is above the threshold $\underline{\omega}$, conditional on the age of the firm, $a_{t}$, and the existing capital stock $k_{t}$.

Since investment is assumed not to be productive until the following period, the firm chooses investment in year $t$ to obtain the optimal level of capital in year $t+1$. The investment decision can thus be written as

$$
i_{t}=i\left(w_{t}, a_{t}, k_{t}\right)
$$

We assume that the firm combines capital, two types of labor, and materials to produce a homogeneous product via a Cobb-Douglas production function. We allow for the possibility of increasing, decreasing or constant returns to scale, assume that productivity differences are Hicks neutral, and assume all firms within an industry face the same price. This latter assumption of identical prices is clearly wrong given the known heterogeneity of products produced within a single industry but is unavoidable given the limitations of the data.

The production function is given by

$$
y_{i t}=\beta_{0}+\beta_{a} a_{i t}+\beta_{k} k_{i t}+\beta_{l} l_{i t}+\beta_{m} m_{i t}+\omega_{i t}+\epsilon_{i t}
$$


where $y_{i t}$ is the log of the value of real production from the firm, $a_{i t}$ is the age of the firm, $k_{i t}$ is the capital stock, $l_{i t}$ is the vector of labor inputs, $m_{i t}$ is the vector of purchased material inputs, $\omega_{i t}$ is the productivity, and $\epsilon_{i t}$ is any unforecastable shock, i.e. either to productivity or prices. We will implement the Olley-Pakes (1996) estimation procedure to address two distinct problems with OLS estimates of the production parameters. First, firms will increase their use of variable inputs, labor and materials, in response to a positive productivity shock that they can observe but is unknown to the econometrician, thus inducing a positive bias in the OLS coefficients on the variable inputs. Second, if plant profitability is positively related to the level of capital, then ceteris paribus firms with greater capital stocks will survive lower realizations of productivity, i.e. the expected future draw of productivity will be negatively related to the capital stock leading to a negative bias in the capital coefficient.

This requires the assumption that investment at date $t$ is an increasing function of known productivity at date $t$, allowing us to write the known component of today's productivity as

$$
\omega_{t}=h\left(i_{t}, a_{t}, k_{t}\right) \text {. }
$$

To address the two concerns about the production function parameter estimates, we first estimate the coefficients on the variable parameters with the semi-parametric estimator

$$
y_{i t}=\beta_{l} l_{i t}+\beta_{m} m_{i t}+\phi_{t}\left(i_{t}, a_{t}, k_{t}\right)+\epsilon_{i t}
$$

where

$$
\phi_{t}\left(i_{t}, a_{t}, k_{t}\right)=\beta_{0}+\beta_{a} a_{i t}+\beta_{k} k_{i t}+h\left(i_{t}, a_{t}, k_{t}\right)
$$

is a fourth order polynomial series estimator in investment, capital, and age.

The estimation in equation 7 does not yield consistent capital coefficients and we still face the problem of a potentially biased coefficient due to the shutdown decision. We estimate the shutdown decision in a probit with age, capital stock, and investment yielding a probability of shutdown, $P_{t}$, for each plant and year.

$$
\operatorname{Pr}\left(\chi_{t+1}=1\right)=\xi_{t}\left(i_{t}, a_{t}, k_{t}\right)=P_{t}
$$


Finally we employ a nonlinear, semi-parametric series estimator to generate consistent coefficients on capital,

$$
\begin{aligned}
y_{i t+1}-\widehat{\beta}_{l} l_{i t+1}-\widehat{\beta}_{m} m_{i t+1}= & \beta_{0}+\beta_{a} a_{i t+1}+\beta_{k} k_{i t+1} \\
& +g\left(P_{t}, \phi_{t}-\beta_{a} a_{i t}-\beta_{k} k_{i t}\right)+\omega_{i t+1}+\epsilon_{i t+1} .
\end{aligned}
$$

From which we can construct our desired measure of plant productive efficiency.

$$
p_{i t}=y_{i t}-\widehat{\beta}_{l} l_{i t}-\widehat{\beta}_{m} m_{i t}-\widehat{\beta}_{a} a_{i t}+\widehat{\beta}_{k} k_{i t}
$$

\subsection{Plant Productivity Growth}

If trade improves productivity by increasing learning at individual firms, we would expect firms involved in international trade to learn more and thus display faster productivity growth. If the knowledge spills over immediately to other firms in the industry, then within industries there would be no differences between exporters and non-exporters but productivity at all firms within export-intensive industries might grow faster than comparable firms in non-export intensive industries.

We look at the relationship between the export status of a plant today and subsequent productivity performance in Table 3. Regressions are of the form

$$
\Delta \ln \text { Productivity }_{i t+1}=\alpha+\beta \text { Exporter }_{i t}+\gamma Z_{i t}+\varepsilon_{i t} .
$$

The set of additional controls, $Z_{i t}$, varies across specifications. Column 1 adds no controls, i.e. just compares mean productivity growth rates at exporters and non-exporters. Column 2 includes year dummies, while columns 3 and 4 adds 2-digit (SIC) and 4-digit industry dummies repsectively, i.e. we are comparing the productivity growth rates of within industries in the same year. Each observation is weighted by its sampling probability in the ASM to generate the universe of manufacturing plants in the U.S..

We find no evidence that the export status of a plant this year is significantly positively correlated with one year ahead productivity growth. For all specifications, we actually obtain negative coefficients; exporters today have productivity growth rates $0.72 \%$ per year lower than similar plants producing solely for the domestic market.

One possible problem might be that we are treating all plants equally in Table 3. Since exporters are more likely to be large plants, we may be underestimating the effect of exporting on productivity growth. In Table 4, 
we weight plants by their initial employment levels. The results do suggest some role for plant size as now the differences are all closer to zero. However, within 4-digit industries, exporters still show significantly lower productivity growth rates.

One explanation for the ordinary productivity performance of exporters is that we are mixing firms that continue exporting, so-called export successes, with those that stop, export failures. Similarly non-exporters today may enter or remain out of the market. To address these issues, we rerun our regressions with three export status dummy variables, one for exporters throughout, i.e. in both periods $[1,1]$, one for firms that leave the export market, stoppers $[1,0]$, and one for new exporters, $[0,1] .{ }^{12}$ The base group is the set of firms that export in neither year. The results, presented in Table 5, do indicate that the four groups have very different productivity trajectories. In particular, in the year that they enter the export market, starters have significantly faster productivity growth rates than other firms. The magnitudes of the total factor productivity growth rate differences for starters are relatively large, ranging from $1.2 \%$ to $2.5 \%$ higher than plants that do not export in either year. Similarly, plants that exit the export market have productivity growth rates $0.2 \%-0.9 \%$ lower than continuing non-exporters.

The results for continuing exporters depend on the specification. Unconditionally, exporters have TFP growth rates that are exactly the same as non-exporters. In part this is because exporting industries have higher TFP growth rates overall. Within industries, we agian find that continuing exporters underperform non-exporters in terms of productivity growth.

The results in this section speak directly to the question of whether an export presence improves subsequent productivity performance at the micro level. Unconditionally, exporters fare no better, and often worse, than non-exporting plants. ${ }^{13}$ This is in large part because of the good productivity performance of entrants and the poor performance of exiting plants. Continuing exporters and continuing non-exporters in the same industry have virtually identical productivity trajectories. If exporting has a role in improving industry productivity growth it must come through some other channel than improving within plant outcomes.

\footnotetext{
${ }^{12}$ We caution that by constructing our variables in such a fashion, we are using ex-post information on the RHS of the regression. No conclusions about directions of causality are warranted.

${ }^{13}$ Over longer horizons, the productivity growth performance of today's exporters is even worse (see Bernard and Jensen 1999).
} 


\subsection{Productivity Before and After Entry (and Exit)}

The previous results show that productivity is correlated with future exporting but exporting is not correlated with subsequent productivity growth. However, the results also show that entry (exit) is associated with large increases (decreases) in productivity. This leaves open the question of what exactly is going on in plants that are entering and exiting the export market. To shed light on these changes, we run a regression of the form

$$
\ln P R_{i j t}=c_{j t}+\sum_{e \in E} \sum_{x \in X} d_{i}^{e} \cdot d_{i j t}^{x}+\varepsilon_{i j t}
$$

where $\ln P R_{i j t}$ is the $\log$ level of the plant productivity measure, $d_{i}^{E}$ is an indicator variable for the export firm type and $d_{i j t}^{x}$ is an indicator variable for the export status of firm that year. We allow 5 firm export types, $d_{i}^{E}$, which are:

- Always - exports in all years

- Starter - becomes an exporter during the period (and does not reswitch)

- Other - switches export status more than once ${ }^{14}$

- Stopper - ceases exporting during the period (and does not reswitch)

- Never - does not export in any year.

We consider five year intervals and thus are able to track firms from two years before entry (or exit), i.e. $d_{i j t}^{x}=-2$, through entry (or exit), i.e. $d_{i j t}^{x}=0$, to two years after entry (or exit), $d_{i j t}^{x}=2$. The interaction of the indicator variables will give us a picture of the relative productivity levels of all five types of firms as they move in and out of exporting.

Figure 3 shows the results for TFP for the different types of firms (omitting the "other" category from the pictures but not the tables); Table 6 contains the coefficients and standard errors. The differences between the types of plants are large, significant, and in the expected directions. Plants that always export are $8 \%-9 \%$ more productive than plants that never export. New entrants into exporting start with productivity levels significantly above continuing non-exporters but significantly below continuing exporters.

\footnotetext{
${ }^{14}$ This group is suppressed in the figures.
} 
Figure 3: Paths of TFP (purged of industry and year effects)

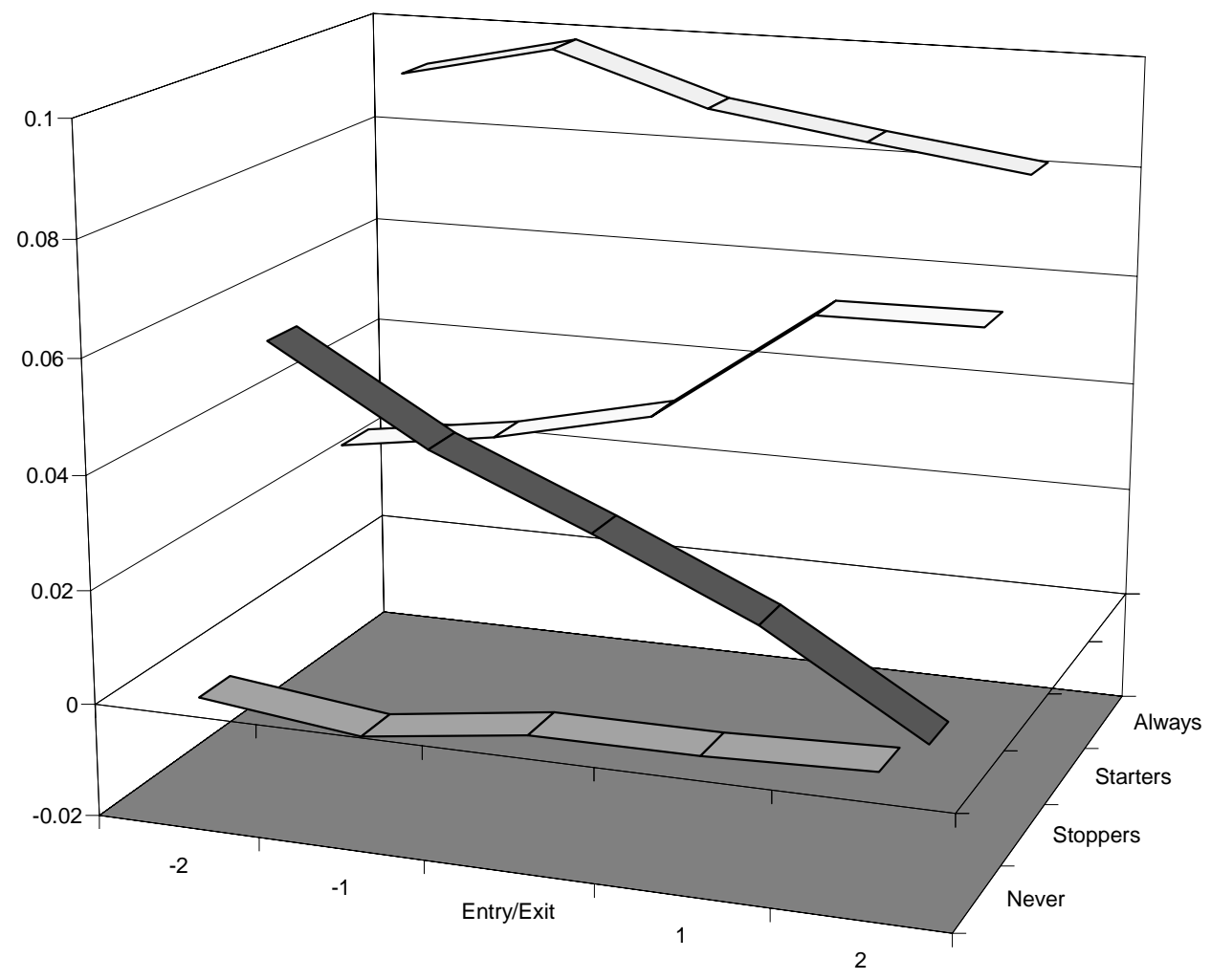


However, the productivity levels of entrants rise before and especially during the year of entry. By the end of the five year window their productivity levels are not significantly below those of plants that exported throughout.

Exits from exporting show comparable deterioration of their productivity levels. They too start below continuers and above non-exporters, but by the end of the period their productivity levels have fallen to those of plants that did not export at all.

\subsection{Plant Growth - Shipments and Employment}

One mechanism by which exporters may contribute to productivity gains in the industry or in the aggregate is through a combination of higher productivity levels and faster overall growth. The evidence present above suggests that high productivity firms enter the export market, rather than exporting leading to high productivity. However, if these high productivity exporters also grow faster, in terms of employment and output, we would expect to see rising industry productivity levels as more firms enter the export market. This kick to industry productivity is not permanent; both before any entry takes place and after all firms have started exporting, the industry growth rate would be completely determined by non-export factors.

In this section we estimate the relationship between overall plant growth, both shipments and employment, and initial export status. We again estimate a regression of the form,

$$
\Delta \ln \text { Size }_{i t+1}=\alpha+\beta \text { Exporter }_{i t}+\gamma Z_{i t}+\varepsilon_{i t},
$$

with similar sets of controls.

The results for employment, total value of shipments, and domestic shipments are given in Table 7 . Unlike productivity growth rates, all measures of firm growth are strongly positively correlated with initial export status. Employment growth is $0.79 \%-1.08 \%$ per year faster at exporters than nonexporters. Results for growth in the total value of shipments range from $0.57 \%-1.32 \%$. The results for domestic shipments are even more dramatic. Exporters expand their domestic shipments between 3\%-4\% faster than nonexporters.

\subsection{Employment Growth Before and After Entry (and Exit)}

The previous results show that employment growth is high for both future exporters and ongoing exporters. Again this leaves open the question of 
what exactly is going on in plants that are entering and exiting the export market. We rerun the specification in Equation ?? with employment growth rates as the dependent variable.

Figure 4 shows the results for employment growth for the different types of firms; Table 8 contains the coefficients and standard errors. The differences between the types of plants are significant and in the expected directions. Plants that always export have employment growth rates $2 \%-4 \%$ higher than plants that never export. New entrants into exporting start with higher employment growth rates than non-exporters, but lower than continuing exporters. These entrants see continued increases in their employment growth rates after they become exporters.

While exporting does not appear to improve productivity growth rates at the plant level, it is strongly correlated with increases in plant size. Both employment and shipments growth are significantly faster at exporters. In particular, these exporting plants increase their domestic shipments substantially faster than non-exporters. Combined with previous work on the productivity advantages in levels for exporters, these results suggest that the reallocation of resources across plants, both within and across industries, may be an important mechanism for trade to affect productivity growth. In the next section we attempt to quantify the aggregate impact of the rapid expansion of exporting plants.

\section{Reallocation of resources within and across industries}

These results suggest that expansion of international trade, and exports in particular, may have effects predicted by standard trade models. Trade enables efficient producers within an industry, and possibly efficient industries within the economy, to expand. As these relatively productive units grow, overall productivity levels rise. The lack of within plant productivity effects indicates that the potential for higher long run productivity growth rates is limited. In light of the evidence presented above, we decompose changes in industry and overall manufacturing productivity growth rates into withinplant and between-plant effects. If our results are correct, we expect to find significant between-plant effects for exporting plants. Some fraction of aggregate productivity growth will be due to the increased scope of activity at high-productivity, exporting establishments. 
Figure 4: Paths of Employment Growth Rates (purged of industry and year effects)

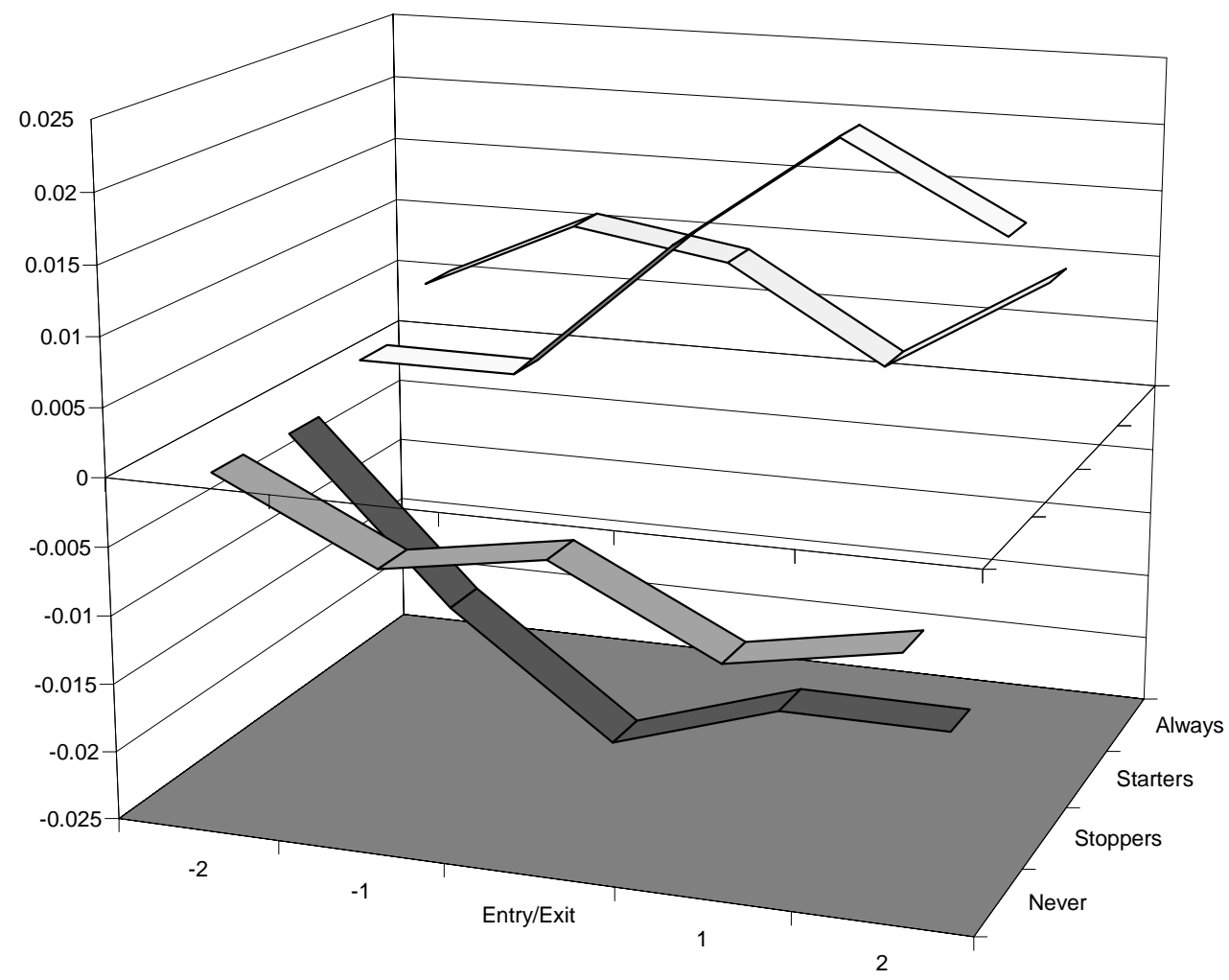




\subsection{Decomposing aggregate productivity growth}

The results on plant level productivity changes suggest that continuous exporting plants do not have significantly higher productivity growth rates than continuous non-exporting plants but that employment and shipments do grow faster at exporters. In this section, we attempt to quantify the importance of the increasing export orientation of U.S. manufacturing on overall manufacturing total factor productivity growth.

We can decompose the annual change in aggregate total factor productivity into within plant (Own) and between-plant (Reallocation) effects, ${ }^{15}$

$$
\Delta P R_{A}=\sum_{i=1}^{I} \Delta\left(P R_{i} \cdot S H_{i}\right)=\underbrace{\sum_{i=1}^{I} \Delta S H_{i} \cdot \overline{P R_{i}}}_{\text {Reallocation Effect }}+\underbrace{\sum_{i=1}^{I} \Delta P R_{i} \cdot \overline{S H}_{i}}_{\text {Own Effect }}
$$

where $P R_{i}$ is the productivity at an individual plant and $S H_{i}$ is the share of total output at the plant.

The reallocation effect is the product of the change in the output share from year $t-1$ to year $t$ at the plant, $\Delta S H_{i}$, and the average total factor productivity in year $t-1$ and $t, \overline{P R_{i}}$. The own productivity effect is the product of the average output share and the change in the plant TFP. ${ }^{16}$

This decomposition, while not unique, allows us to quantify the degree to which more productive plants are growing or plants are growing more productive. A positive share effect results from an increasing share of total output at plants with higher than average productivity. The own effect is positive if the mean of output weighted within-plant productivity growth is positive. This component will be dominated by plants with relatively large productivity changes in levels and/or large plants with positive productivity growth. Of course, if the high productivity plants have the highest productivity growth rates then the own effect will be large.

An advantage of the decomposition presented above is that we can group plants into categories, i.e. four-digit industries or export status of the plant. We transform the decomposition given above into one for aggregate produc-

\footnotetext{
${ }^{15}$ For our decomposition analysis, we work only with continuing plants, i.e. plants that exist in years $t$ and $t+1$. The exclusion of plant failures and plant births does not have a significant effect on our results.

${ }^{16}$ We calculate the components year by year for each plant and then average across all the years in the sample.
} 
tivity growth rates,

$$
\Delta P R_{A}=\underbrace{\sum_{j=1}^{J} \sum_{i \in j} \Delta S H_{i} \cdot \overline{P R_{i}}}_{\text {Reallocation Effect }}+\underbrace{\sum_{j=1}^{J} \sum_{i \in j} \Delta P R_{i} \cdot \overline{S H_{i}}}_{\text {Own Effect }}
$$

where $j$ represents the group for plant $i$. We choose to cluster plants into four groups based on their export status in the two years (starter, throughout, stopper, and neither). We then can compute the fraction of overall growth due to growth of plants in each category and due to within-plant productivity growth in each category.

In Tables 9 and 10, we decompose annual average aggregate TFP growth for continuing plants in the manufacturing sector, without and with the computer-related sectors (SIC 3571, 3572, 3575, and 3577) respectively. ${ }^{17}$ Overall TFP at continuing manufacturing plants grew at average annual rate of $1.42 \%$ from 1983 to 1992 .

While the dominant source of aggregate productivity growth was the own-productivity effect, accounting for $58 \%$ of the total, changes in output shares among plants were surprisingly important in overall growth. $42 \%$ of aggregate TFP growth came about because of increasing output shares at more productive plants. These estimates suggest important roles for the reallocation of resources towards more productive plants. ${ }^{18}$

Our results so far have suggested that continuing exporters grew substantially faster in terms of employment and output and thus should account for the preponderance of any reallocation effects. The decomposition results confirm this hypothesis as over $87 \%$ of overall TFP growth comes from the expansion of continuing exporters. The net effect of entrant and exits from exporting is slightly positive in terms of the change in output shares while continuing non-exporters show negative reallocation components due to their slower than average output growth. Put in other terms, had there been no changes in relative output shares across plants, TFP growth in the manufacturing sector would have been $0.82 \%$ instead of $1.42 \%$ per year.

\footnotetext{
${ }^{17}$ The computer industry represents a problem in the 1972 SIC classification due to difficulties with the output deflator. Our general conclusions are not sensitive to the inclusion of the sector and the regression results presented earlier are not affected.

${ }^{18}$ Baily, Hulten and Campbell (1992) estimate reallocation effects of $31 \%$ for the period 1972-1987 using similar methods. Aw, Chen, and Roberts (1997) find that within-firm productivity growth and firm entry and exit play large roles in productivity growth in Taiwan and reallocation across plants plays only a minor role.
} 
Turning to the own productivity components, we find once again that continuing exporting plants are by far the most important group, with own productivity effects more than four times as large as continuing nonexporters. This may seem surprising after the plant level results which showed no relative productivity growth advantage for exporters (or even continuing exporters). However, plants with high initial productivity levels will contribute more to aggregate productivity growth than plants with low productivity levels, even if they have the same growth rates. Exporters are substantially more productive than non-exporters in the same industry, and they are more likely to be located in high productivity industries. This combination of level effects leads exporters to contribute disproportionately to aggregate growth.

One question is whether these reallocation effects are occurring within or across industries. Most trade theories use the industry as the unit of analysis and hypothesize gains from cross-industry changes. The industry regressions of the previous section imply that the cross-industry magnitudes are small. The decomposition above argues that cross-plant magnitudes are substantial. An industry-level decomposition reported in Table 11 shows that just under half of the reallocative activity (22.5\%) occurred within 4digit industries and half occurred because of changing output shares across industries (19.4\%). The big impact on manufacturing productivity of fast growth at exporting plants is as much a within-industry phenomenon as it is one of the relative rise and fall of different sectors.

These decompositions certianly overstate the role of trade in the reallocation of resources and overall total factor productivity growth. We know that domestic shipments also grow more quickly at exporting plants, and that exports typically make up only a small fraction of plant output.. To provide a better estimate of the relative importance of domestic and foreign shipments we further break out reallocation and own-productivity effects into domestic and foreign components. The decomposition is given by

$$
\Delta P R_{A}=\underbrace{\sum_{j=1}^{J} \sum_{i \in j} \Delta D S H_{i} \cdot \overline{P R_{i}}}_{\text {Domestic Reallocation Effect }}+\underbrace{\sum_{j=1}^{J} \sum_{i \in j} \Delta F S H_{i} \cdot \overline{P R_{i}}}_{\text {Foreign Reallocation Effect }}
$$




$$
+\underbrace{\sum_{j=1}^{J} \sum_{i \in j} \Delta P R_{i} \cdot \overline{D S H}_{i}}_{\text {Domestic Own Effect }}+\underbrace{\sum_{j=1}^{J} \sum_{i \in j} \Delta P R_{i} \cdot \overline{F S H}_{i}}_{\text {Foreign Own Effect }}
$$

where $D S H_{i}$ is the ratio of domestic shipments by the plant to total manufacturing output and $F S H_{i}$ is the ratio of exports by the plant to total manufacturing output. We assume for this analysis that productivity levels are the same within plants for both types of shipments. The results are presented in Table 12 .

As expected, continuing exporters show positive reallocation contributions for both domestic and foreign shipments. This confirms that these plants are in general growing faster. However, the increases in foreign shipments at these plants are the main source of reallocative activity. Fully $70 \%$ of the reallocation effect at continuing exporters is due to export growth. In contrast, exports contribute relatively little to the own-productivity effects $(12 \%)$. This is because exports, while growing rapidly, remain a relatively small share of total shipments at exporting plants.

Since these decompositions are not unique, we cannot use them to quantify the importance of exporting to aggregate productivity growth. However, in an effort to provide a sense of the importance of these effects, we focus on two numbers which most likely bound the importance of the role of exporting to TFP growth. The first comes from the results reported in Table 13. Summing the reallocative effects and own-productivity effects for continuing exporters attributed to foreign shipments, we find an upper bound of $65 \%$ of aggregate TFP growth. We caution that this is certainly a large overstatement of the importance of exporting in aggregate manufacturing.

To calculate a lower bound, we assume that the paths for productivity and doemstic shipments for plants would not change if they had no access to the foreign market. We then reestimate our decomposition in Table 10, eliminating exports from total shipments and recalculating plant output shares. This increases the importance of non-exporters, but also assumes that in the absence of a foreign market exporters could not further increase their domestic market share. The new counterfactual decomposition is given in Table 14. As expected the bulk of the change in aggregate productivity is concentrated mostly in the reallocative effect which falls $15 \%$. Aggregate TFP growth under these assumptions falls by $7.8 \%$ which represents our lower bound for the importance of exporting to aggregate TFP growth. 


\subsection{Exporting and Importing Industries}

Finally we return to the role of imports in aggregate productivity growth. As mentioned earlier we have no information on imported intermediate inputs at the plant level. We instead use information on imports and exports at the 4-digit industry level. We divide industries into five categories based on their export and import intensity at the beginning of the sample and calculate the reallocation and own-productivity effects ${ }^{19}$.

- Trade intensive - top quartile in both export and import intensity [7\% of industries, $5.0 \%$ of employment]

- Export intensive - top quartile in export intensity but not in import intensity [ $18 \%$ of industries, $24.5 \%$ of employment]

- Import intensive - top quartile in export intensity but not in import intensity [ $18 \%$ of industries, $12.4 \%$ of employment]

- Non-tradeable - bottom quartile in both export and import intensity [ $12 \%$ of industries, $14.7 \%$ of employment]

- Other - remaining industries [45\% of industries, $43.4 \%$ of employment]

Table 14 reports the reallocation and own-productivity effects for the five industry types while Table 15 reports the contributions of different plant types within industries. As expected from the earlier decompositions, both types of export-intensive industries show large positive reallocative effects. In contrast, import competing and non-tradable industries are growing more slowly and have large negative reallocative contributions. Interestingly the non-tradable sector also has declining plant level productivity growth over the sample leading to a negative own-productivity contribution.

Given the importance of exporting in reallocation, the results from Table 16 are perhaps not that surprising. However, when we look within sectors in Table 15, we once again find a dominant role for exporting plants, even in the import-competing and non-tradable industries. Starters and continuing exporters dominate both the reallocative and the own-productivity contributions to aggregate productivity growth in all industries types. Whle we emphasize that productivity growth at these plants is not enhanced by exporting the faster shipments gorwth leads to a disproportionate contribution to aggregate TFP growth even in 'non-export' sectors.

\footnotetext{
${ }^{19}$ Relative trade intensities are largely unchanged across the sample.
} 


\section{Conclusions}

The interplay between productivity and international trade has implications for a wide variety of fields in economics from the cross-country study of long run growth to the evolution of inequality within countries. In this paper, we have explored the relationship between productivity and exporting in the U.S. manufacturing sector. Building on previous research, we have found little evidence that exporting per se is associated with faster productivity growth rates at individual plants. The positive correlation between exporting and productivity levels appears to come from the fact that high productivity plants are more likely to enter foreign markets. The productivity path for a plant moving switching from non-exporter to exporter shows a rise in productivity levels before and during entry, and a flat trajectory thereafter.

High productivity before entry is not the end of the story. Our results show that employment and output growth rates are much higher at exporters and employment growth continues to increase after entry. This faster growth of exporting plants, coupled with their higher productivity levels, provides an alternative, reallocative mechanism for exporting to augment aggregate productivity growth.

The magnitudes of these shifts of employment towards high productivity exporters are quite large. From 1983-1992, more than $40 \%$ of total factor productivity growth in the manufacturing sector resulted from changing output shares across plants. Almost all of these reallocative effects resulted because high productivity exporters grew faster than lower productivity nonexporters. Exporters account for $46 \%$ of total employment in our sample but contribute a far greater percentage to aggregate TFP growth. Even in nontradable and import-competing sectors, exporters grow faster and contribute substantially to aggregate productivity growth.

Our results provide the first direct evidence on the possible role for trade in increasing economic growth. None of the existing theories about the trade-productivity relationship fit the data exactly. If trade, via exporting, facilitates knowledge transfer, it does not show up either at the plant or industry level in our results. The predictions of traditional, static trade models appear to be closer to the mark although the interesting reallocations take place within industries, not across them. Trade improves welfare by facilitating the growth of high productivity plants, not by increasing productivity growth at those plants. The results contain both good news and bad news for long run growth rates. Increased trade will contribute to aggregate productivity growth, but the effect is one of increased levels, rather 
than an increase in the long-run growth rate itself. However, the magnitude of these 'one-time' level changes are large and, given the relatively low export shares for U.S. industries, are far from being exhausted.

The results presented here suggest that the within-industry effects of trade may be as, or more, important than the cross-industry effects. Much work remains to be completed to develop our understanding of the impact of international trade on productivity growth, especially concerning the role of imports on productivity and employment. Of particular interest is an examination of the role of international trade as a force for efficient reallocation of resources in countries away from the technology and productivity frontier.

\section{A Appendix - Plant Capital Stocks}

Unfortunately the data on plant level capital stocks were not collected for the years 1988-1991. To construct plant measures of TFP we must construct proxies for plant capital from initial or ending year capital stocks and the data on investment in the intervening years using a perpetual inventory method. Since we do not directly observe depreciation we calculate an average depreciation from the years for which we have full information on capital stocks and investment. Every plant in our sample appears in either the 1987 or 1992 Census of Manufactures or both. We construct separate estimated capital stocks from each endpoint and for plants in the sample in both 1987 and 1992 we use the average of the estimates.

$$
\begin{aligned}
& \vec{K}_{i, 1987+m}=(1-\delta)^{m} \cdot K_{i, 1987}+\sum_{s=1}^{m}(1-\delta)^{s-1} \cdot I N V_{i, 1987+s} \\
& \overleftarrow{K}_{i, 1992-j}=\left(\frac{1}{1-\delta}\right)^{j} \cdot K_{i, 1992}-\sum_{s=1}^{j}\left(\frac{1}{1-\delta}\right)^{j-s+1} \cdot I N V_{i, 1992-s} \\
& \overleftrightarrow{K}_{i t}=\frac{\frac{1}{2}\left(\overleftarrow{K}_{i, t}+\vec{K}_{i, t}\right)}{\max \left(\overleftarrow{K}_{i, t}, \vec{K}_{i, t}\right)} \quad \text { if both } \vec{K}_{i, t} \text { and } \overleftarrow{K}_{i, t} \text { exist }
\end{aligned}
$$




\section{References}

Aw, Bee Yan, Xiaomin Chen, and Mark J. Roberts. (1997) "FirmLevel Evidence on Productivity Differentials, Turnover, and Exports in Taiwanese Manufacturing," NBER Working Paper No. 6235.

Aw, Bee and A. R. Hwang, (1995). "Productivity and the Export Market: A Firm-Level Analysis" Journal of Development Economics; 47(2), pages 313-32.

Bailey, Martin N., Charles Hulten, and David Campbell (1992) "Productivity Dynamics in Manufacturing Plants." Brookings Papers on Economic Activity, Microeconomics. Washington DC.

Ben-David, Dan (1993). "Equalizing Exchange: Trade Liberalization and Income Convergence." Quarterly Journal of Economics, Vol. 108, pp. 653-679.

Ben-David, Dan and Michael Loewy (1998) "Free Trade, Growth, and Convergence." Journal of Economic Growth, 3, 143-170.

Bernard, Andrew B. and J. Bradford Jensen. (1995). "Exporters, Jobs, and Wages in U.S. Manufacturing, 1976-1987." Brookings Papers on Economic Activity, Microeconomics. Washington DC.

Bernard, Andrew B. and J. Bradford Jensen. (1997). "Why Some Firms Export: Experience, Entry Costs, Spillovers, and Subsidies." Yale mimeo.

Bernard, Andrew B. and J. Bradford Jensen. (1999). "Exceptional Exporter Performance: Cause, Effect, or Both?." Journal of International Economics Vol 47, No.1, 1-26.

Bernard, Andrew B. and Joachim Wagner. (1997). "Exports and Success in German Manufacturing." Weltwirtschaftliches Archiv, 133(1), 134-157.

Bernard, Andrew B. and Joachim Wagner. (1998). "Export Entry and Exit by German Firms." NBER Working Paper No. 6538.

Clerides, Sofronis, Saul Lach and James Tybout. (1998) "Is "Learningby-Exporting" Important?" Quarterly Journal of Economics, August, pp. 903-948. 
Ericson, Richard and Ariel Pakes. (1995) "Markov-Perfect Industry Dynamics: A Framework for Empirical Work," Review of Economic Studies, 62(1), 53-82.

Feeney, Joanne. (1999) "International Risk Sharing, Learning By Doing, and Growth" Journal of Development Economics, forthcoming.

Feenstra, Robert. (1996) "Trade and Uneven Growth", Journal of Development Economics, 49, 229-256.

Grossman, Gene and Elhanan Helpman, (1991) Innovation and Growth in the Global Economy, Cambridge: MIT Press.

Henriques, Irene and Perry Sadorsky. (1996). "Export-Led Growth or Growth-Driven Exports? The Canadian Case" Canadian Journal of Economics, 29(3), pages 540-55.

Krugman, Paul and Robert Lawrence. (1993) "Trade, Jobs, and Wages." NBER Working Paper No. 4478.

Leamer, Edward (1996) "Wage Inequality from International Competition and Technological Change: Theory and Country Experience" American Economic Review;86(2) pages 309-14.

Olley, Steven G. and Ariel Pakes, (1996) "The Dynamics of Productivity in the Telecommunications Equipment Industry," Econometrica, 64(6), 1263-97.

Proudman, James and Steven Redding (eds). (1998) Openness and Growth, Bank of England, London.

Rivera-Batiz, Luis A. and Paul Romer. (1991) "Economic Integration and Endogenous Growth," Quarterly Journal of Economics, 106, 531555 .

Roberts, Mark and James Tybout. (1997). "The Decision to Export in Columbia: An Empirical Model of Entry with Sunk Costs." American Economic Review, 87(4), 545-564.

Romer, Paul. (1994) "New Goods, Old Theory and the Welfare Costs of Trade Restrictions," Journal of Development Economics, 43, 5-38. 
Sachs, Jeffrey, and Andrew Warner. (1995) "Economic Reform and the Process of Global Integration" Brookings Papers on Economic Activity, No 1, 1-95, Washington DC.

Slaughter, Matthew (1998) "International Trade and Per Capita Income Convergence: A Differences in Differences Approach." NBER Working Paper No. $655 \%$.

U.S. Bureau of the Census. (1987). Census of Manufactures General Summary MC87-S-1. Department of Commerce. 
EXPORTING AND PRODUCTIVITY

Table 1 : Testing Aggregate Causality - Exports and Productivity Growth (1960-1996)

\begin{tabular}{|c|c|c|c|c|}
\hline & $\begin{array}{c}\Delta \text { Labor } \\
\text { Productivity } \\
\text { (1) }\end{array}$ & $\begin{array}{l}\Delta \text { Log Real } \\
\text { Exports } \\
\text { (2) }\end{array}$ & $\begin{array}{l}\Delta \text { Multi-Factor } \\
\text { Productivity } \\
\text { (3) }\end{array}$ & $\begin{array}{l}\Delta \text { Log Real } \\
\text { Exports } \\
\text { (4) }\end{array}$ \\
\hline$\Delta$ Labor productivity $(\mathrm{t}-1)$ & $\begin{array}{c}0.263 \\
(0.195)\end{array}$ & $\begin{array}{l}-0.001 \\
(0.082)\end{array}$ & & \\
\hline$\Delta$ Labor productivity $(\mathrm{t}-2)$ & $\begin{array}{l}-0.247 \\
(0.188)\end{array}$ & $\begin{array}{c}0.238 * * \\
(0.106)\end{array}$ & & \\
\hline$\Delta$ Labor productivity $(\mathrm{t}-3)$ & $\begin{array}{l}-0.118 \\
(0.230)\end{array}$ & $\begin{array}{c}0.139 \\
(0.087)\end{array}$ & & \\
\hline$\Delta$ Multi-factor productivity $(\mathrm{t}-1)$ & & & $\begin{array}{c}0.329 * \\
(0.191)\end{array}$ & $\begin{array}{c}0.099 * \\
(0.077)\end{array}$ \\
\hline$\Delta$ Multi-factor productivity $(\mathrm{t}-2)$ & & & $\begin{array}{l}-0.241 \\
(0.153)\end{array}$ & $\begin{array}{c}0.118 \\
(0.112)\end{array}$ \\
\hline$\Delta$ Multi-factor productivity $(\mathrm{t}-3)$ & & & $\begin{array}{c}0.220 \\
(0.138)\end{array}$ & $\begin{array}{l}-0.011 \\
(0.075)\end{array}$ \\
\hline$\Delta$ Log real exports (t-1) & $\begin{array}{l}-0.294 \\
(0.393)\end{array}$ & $\begin{array}{c}0.069 \\
(0.175)\end{array}$ & $\begin{array}{l}-1.331 * * \\
(0.592)\end{array}$ & $\begin{array}{l}0.144 * * \\
(0.200)\end{array}$ \\
\hline$\Delta$ Log real exports ( $\mathrm{t}-2)$ & $\begin{array}{l}-0.114 \\
(0.335)\end{array}$ & $\begin{array}{c}0.000 \\
(0.213)\end{array}$ & $\begin{array}{l}-0.493 \\
(0.434)\end{array}$ & $\begin{array}{l}-0.023 \\
(0.210)\end{array}$ \\
\hline$\Delta$ Log real exports (t-3) & $\begin{array}{l}-0.010 \\
(0.321)\end{array}$ & $\begin{array}{c}0.039 \\
(0.191) \\
\end{array}$ & $\begin{array}{c}0.116 \\
(0.433)\end{array}$ & $\begin{array}{c}0.092 \\
(0.294)\end{array}$ \\
\hline $\begin{array}{l}\mathrm{R}^{2} \\
\mathrm{~N}\end{array}$ & $\begin{array}{l}0.20 \\
33\end{array}$ & $\begin{array}{l}0.38 \\
33\end{array}$ & $\begin{array}{l}0.45 \\
33\end{array}$ & $\begin{array}{l}0.23 \\
33\end{array}$ \\
\hline
\end{tabular}

All regressions were run with Huber-White corrections. $* * *$ indicates significance at the $1 \%$ level. $* *$ indicates significance at the 5\% level. * indicates significance at the $10 \%$ level. 
Table 2 : Testing Industry Causality - Exports and Productivity Growth (1958-1994)

\begin{tabular}{|c|c|c|c|c|}
\hline & $\begin{array}{c}\Delta \text { Labor } \\
\text { Productivity } \\
\text { (1) }\end{array}$ & $\begin{array}{l}\Delta \text { Log Real } \\
\text { Exports } \\
\text { (2) }\end{array}$ & $\begin{array}{l}\Delta \text { Multi-Factor } \\
\text { Productivity } \\
\text { (3) }\end{array}$ & $\begin{array}{l}\Delta \text { Log Real } \\
\text { Exports } \\
\text { (4) }\end{array}$ \\
\hline$\Delta$ Labor productivity $(\mathrm{t}-1)$ & $\begin{array}{l}-0.162 * * * \\
(0.023)\end{array}$ & $\begin{array}{l}0.125 * * * \\
(0.028)\end{array}$ & & \\
\hline$\Delta$ Labor productivity $(\mathrm{t}-2)$ & $\begin{array}{l}-0.114 * * * \\
(0.017)\end{array}$ & $\begin{array}{l}0.091 * * * \\
(0.034)\end{array}$ & & \\
\hline$\Delta$ Labor productivity $(\mathrm{t}-3)$ & $\begin{array}{l}-0.097 * * * \\
(0.016)\end{array}$ & $\begin{array}{l}0.063^{* * * *} \\
(0.024)\end{array}$ & & \\
\hline$\Delta$ Multi-factor productivity $(\mathrm{t}-1)$ & & & $\begin{array}{l}-0.045^{*} \\
(0.024)\end{array}$ & $\begin{array}{l}0.220^{* * *} \\
(0.044)\end{array}$ \\
\hline$\Delta$ Multi-factor productivity $(\mathrm{t}-2)$ & & & $\begin{array}{l}-0.105^{* * *} \\
(0.019)\end{array}$ & $\begin{array}{l}0.122 * * * \\
(0.046)\end{array}$ \\
\hline$\Delta$ Multi-factor productivity $(\mathrm{t}-3)$ & & & $\begin{array}{l}-0.044 * * * \\
(0.015)\end{array}$ & $\begin{array}{c}0.057 \\
(0.041)\end{array}$ \\
\hline$\Delta$ Log real exports (t-1) & $\begin{array}{l}-0.016 * * * \\
(0.005)\end{array}$ & $\begin{array}{l}-0.013 \\
(0.019)\end{array}$ & $\begin{array}{l}-0.006^{* *} \\
(0.002)\end{array}$ & $\begin{array}{l}-0.018 \\
(0.019)\end{array}$ \\
\hline$\Delta$ Log real exports ( $\mathrm{t}-2)$ & $\begin{array}{l}-0.019 * * * \\
(0.004)\end{array}$ & $\begin{array}{l}-0.035 \\
(0.023)\end{array}$ & $\begin{array}{l}-0.007 * * * \\
(0.002)\end{array}$ & $\begin{array}{l}-0.038 \\
(0.023)\end{array}$ \\
\hline$\Delta$ Log real exports (t-3) & $\begin{array}{c}0.005 \\
(0.004)\end{array}$ & $\begin{array}{l}-0.007 \\
(0.016)\end{array}$ & $\begin{array}{c}0.003 \\
(0.003)\end{array}$ & $\begin{array}{l}-0.009 \\
(0.016)\end{array}$ \\
\hline $\begin{array}{l}\mathrm{R}^{2} \\
\mathrm{~N}\end{array}$ & $\begin{array}{l}0.043 \\
14110\end{array}$ & $\begin{array}{r}0.005 \\
14110\end{array}$ & $\begin{array}{l}0.017 \\
14110\end{array}$ & $\begin{array}{l}0.005 \\
14110\end{array}$ \\
\hline
\end{tabular}

434 industries are included. All regressions were run with Huber-White corrections. *** indicates significance at the $1 \%$ level. $* *$ indicates significance at the $5 \%$ level. * indicates significance at the $10 \%$ level. 
Table 3 : Exporters and TFP Growth ${ }^{1}$

(Dependent variable: annual plant TFP growth rates)

\begin{tabular}{|c|c|c|c|c|}
\hline Export Dummy & $\begin{array}{l}-0.0021 \\
(0.0013)\end{array}$ & $\begin{array}{l}-0.0020 \\
(0.0013)\end{array}$ & $\begin{array}{l}-0.0056^{* * *} \\
(0.0014)\end{array}$ & $\begin{array}{l}-0.0072 * * * \\
(0.0015)\end{array}$ \\
\hline $\begin{array}{l}\text { Year Dummies } \\
\text { Industry Dummies (2-digit) } \\
\text { Industry Dummies (4-digit) }\end{array}$ & & $\mathrm{X}$ & $\begin{array}{l}X \\
X\end{array}$ & $\begin{array}{l}X \\
X\end{array}$ \\
\hline
\end{tabular}

Table 4 : Exporters and TFP Growth ${ }^{2}$

(Dependent variable: annual plant TFP growth rates)

\begin{tabular}{|llrrr|}
\hline & & & & \\
& 0.0012 & $0.0018^{*}$ & -0.0010 & $-0.0045^{* * *}$ \\
& $(0.0010)$ & $(0.0010)$ & $(0.0011)$ & $(0.0012)$ \\
Year Dummies & & $\mathrm{X}$ & $\mathrm{X}$ & $\mathrm{X}$ \\
Industry Dummies (2-digit) & & & $\mathrm{X}$ & $\mathrm{X}$ \\
Industry Dummies (4-digit) & & & $\mathrm{X}$ \\
\hline
\end{tabular}

${ }^{2}$ Observations are weighted by the product of total employment at the plant and the sampling probability of the plant in the ASM. All regressions were run with Huber-White corrections. $* * *$ indicates significance at the $1 \%$ level. ** indicates significance at the 5\% level. * indicates significance at the $10 \%$ level. Plant controls include (log ) total employment, average wage, and share of non-production workers in total employment. 
Table 5 : Export Status and Productivity Growth ${ }^{1}$

(Dependent variable: annual plant TFP growth rates)

\begin{tabular}{|lcclc|}
\hline Export Status & & & & \\
Stopper $(1,0)$ & -0.0023 & $-0.0045^{*}$ & $-0.0075^{* * *}$ & $-0.0092^{* * *}$ \\
& $(0.0025)$ & $(0.0025)$ & $(0.0025)$ & $(0.0025)$ \\
Throughout $(1,1)$ & 0.0000 & 0.0004 & $-0.0030^{* * *}$ & $-0.0040^{* *}$ \\
& $(0.0015)$ & $(0.0015)$ & $(0.0015)$ & $(0.0016)$ \\
Starter $(0,1)$ & $0.0250^{* * *}$ & $0.0200^{* * *}$ & $0.0170^{* * *}$ & $0.0156^{* * *}$ \\
& $(0.0024)$ & $(0.0024)$ & $(0.0024)$ & $(0.0024)$ \\
Year Dummies & & & & $\mathrm{X}$ \\
Industry Dummies (2-digit) & & $\mathrm{X}$ & $\mathrm{X}$ & $\mathrm{X}$ \\
Industry Dummies (4-digit) & & & & \\
\hline
\end{tabular}

${ }^{1}$ Coefficients represent differences from growth rates at plants that did not export in either year, $(0,0)$.

Observations are weighted by the product of plant employment and the ASM sampling probabilities. All regressions were run with Huber-White corrections. $* * *$ indicates significance at the $1 \%$ level. ** indicates significance at the $5 \%$ level. * indicates significance at the $10 \%$ level. Plant controls include (log) total employment, average wage, and share of non-production workers in total employment. 
Table 6: TFP Before, During and After Entry (or Exit)

\begin{tabular}{|c|c|c|c|c|c|}
\hline & \multicolumn{4}{|c|}{ Export Type } & \\
\cline { 2 - 6 } & Never & Stoppers & Other & Starters & Always \\
\hline \multirow{2}{*}{-2} & 0 & $0.055^{*^{+}}$ & $0.024^{*^{+}}$ & $0.029^{*^{+}}$ & $0.093^{*}$ \\
& & $(0.011)$ & $(0.009)$ & $(0.011)$ & $(0.008)$ \\
& -0.003 & $0.039^{*^{+}}$ & $0.031^{*^{+}}$ & $0.033^{*^{+}}$ & $0.099^{*}$ \\
& $(0.006)$ & $(0.010)$ & $(0.008)$ & $(0.010)$ & $(0.007)$ \\
& 0.001 & $0.027^{*+}$ & $0.020^{*^{+}}$ & $0.040^{*^{+}}$ & $0.090^{*}$ \\
& $(0.007)$ & $(0.009)$ & $(0.008)$ & $(0.009)$ & $(0.008)$ \\
& 0.001 & $0.014^{+}$ & $0.024^{*^{+}}$ & $0.060^{*}$ & $0.085^{*}$ \\
& $(0.008)$ & $(0.011)$ & $(0.009)$ & $(0.011)$ & $(0.008)$ \\
& -0.002 & $-0.004^{+}$ & $0.024^{*+}$ & $0.061^{*}$ & $0.082^{*}$ \\
& $(0.009)$ & $(0.013)$ & $(0.011)$ & $(0.013)$ & $(0.010)$ \\
\hline
\end{tabular}

* indicates that the coefficient is significantly different from Never(-2) at the $5 \%$ level. ${ }^{+}$indicates that the coefficient is significantly different from Always $(+2)$ at the $5 \%$ level. 
Table 7 : Exporters and Plant Growth ${ }^{1}$

(Coefficients on exporter dummies in year ahead growth regessions)

\begin{tabular}{|c|c|c|c|c|}
\hline \multicolumn{5}{|l|}{ Dependent Variable } \\
\hline Employment Growth & $\begin{array}{l}0.0108 * * * \\
(0.0013)\end{array}$ & $\begin{array}{l}0.0091 * * * \\
(0.0013)\end{array}$ & $\begin{array}{l}0.0096 * * * \\
(0.0013)\end{array}$ & $\begin{array}{l}0.0079 * * * \\
(0.0014)\end{array}$ \\
\hline Total Shipments Growth & $\begin{array}{l}0.0132 * * * \\
(0.0015)\end{array}$ & $\begin{array}{l}0.0113 * * * \\
(0.0015)\end{array}$ & $\begin{array}{l}0.0079 * * * \\
(0.0016)\end{array}$ & $\begin{array}{l}0.0057 \text { *** } \\
(0.0017)\end{array}$ \\
\hline Domestic Shipments Growth & $\begin{array}{l}0.0364 * * * \\
(0.0015)\end{array}$ & $\begin{array}{l}0.0344 * * * \\
(0.0015)\end{array}$ & $\begin{array}{l}0.0337 * * * \\
(0.0016)\end{array}$ & $\begin{array}{l}0.0302 * * * \\
(0.0023)\end{array}$ \\
\hline \multicolumn{5}{|l|}{ Additional Controls } \\
\hline $\begin{array}{l}\text { Year Dummies } \\
\text { Industry Effects (2-digit) } \\
\text { Industry Effects (4-digit) }\end{array}$ & & $\mathrm{X}$ & $\begin{array}{l}X \\
X\end{array}$ & $\mathrm{X}$ \\
\hline
\end{tabular}


Table 8: Employment Growth Rates Before, During and After Entry (or Exit)

\begin{tabular}{|c|c|c|c|c|c|}
\hline & \multicolumn{4}{|c|}{ Export Type } & \multirow[b]{2}{*}{ Always } \\
\hline & Never & Stoppers & Other & Starters & \\
\hline-2 & 0 & $\begin{array}{r}0.0000^{+} \\
(0.0106)\end{array}$ & $\begin{array}{r}0.0097^{+} \\
(0.0050)\end{array}$ & $\begin{array}{r}0.0050^{+} \\
(0.0106)\end{array}$ & $\begin{array}{c}0.0271 * \\
(0.0052)\end{array}$ \\
\hline-1 & $\begin{array}{c}-0.0055^{+} \\
(0.0096)\end{array}$ & $\begin{array}{l}-0.0083^{+} \\
(0.0089)\end{array}$ & $\begin{array}{c}0.0105 \\
(0.0097)\end{array}$ & $\begin{array}{c}0.0151 \\
(0.0092)\end{array}$ & $\begin{array}{r}0.0325^{*} \\
(0.0097)\end{array}$ \\
\hline 0 & $\begin{array}{c}-0.0111^{+} \\
(0.0105)\end{array}$ & $\begin{array}{c}-0.0081^{+} \\
(0.0113)\end{array}$ & $\begin{array}{c}0.0062 \\
(0.0106)\end{array}$ & $\begin{array}{r}0.0350^{*} \\
(0.0114)\end{array}$ & $\begin{array}{c}0.0231^{*} \\
(0.0106)\end{array}$ \\
\hline+1 & $\begin{array}{l}-0.0106^{+} \\
(0.0122)\end{array}$ & $\begin{array}{l}-0.0122^{+} \\
(0.0125)\end{array}$ & $\begin{array}{c}0.0120 \\
(0.0123)\end{array}$ & $\begin{array}{c}0.0383^{*} \\
(0.0126)\end{array}$ & $\begin{array}{c}0.0370^{*} \\
(0.0122)\end{array}$ \\
\hline+2 & $\begin{array}{c}0.0170 \\
(0.0138)\end{array}$ & $\begin{array}{l}-0.0033^{+} \\
(0.0145)\end{array}$ & $\begin{array}{c}0.0412 * \\
(0.0139)\end{array}$ & $\begin{array}{c}0.0402 * \\
(0.0145)\end{array}$ & $\begin{array}{c}0.0496 * \\
(0.0139)\end{array}$ \\
\hline
\end{tabular}

* indicates that the coefficient is significantly different from Never(-2) at the $5 \%$ level. ${ }^{+}$indicates that the coefficient is significantly different from Always(+2) at the 5\% level. 
Table 9: Decomposition of Manufacturing TFP Growth by Plant Type (all sectors)

\begin{tabular}{|l|c|c|c|}
\hline \multirow{2}{*}{ Export Status } & Reallocation Effect & Own-Productivity Effect & Overall \\
\cline { 2 - 4 } & \multicolumn{3}{|c|}{ Growth Rates } \\
Stopper $(1,0)$ & -0.0041 & -0.0003 & -0.0044 \\
Throughout $(1,1)$ & 0.0123 & 0.0055 & 0.0178 \\
Starter $(0,1)$ & 0.0045 & 0.0014 & 0.0059 \\
Neither (0,0) & -0.0067 & 0.0016 & -0.0051 \\
& & 0.0082 & 0.0142 \\
All & 0.0059 & $\%$ of Total Growth Rate \\
\hline \multicolumn{3}{|c|}{$-1.8 \%$} & $-30.7 \%$ \\
Stopper (1,0) & $-28.9 \%$ & $38.7 \%$ & $125.5 \%$ \\
Throughout $(1,1)$ & $86.8 \%$ & $10.0 \%$ & $41.3 \%$ \\
Starter $(0,1)$ & $31.4 \%$ & $11.2 \%$ & $-36.1 \%$ \\
Neither $(0,0)$ & $-47.3 \%$ & $58.1 \%$ & $100.0 \%$ \\
All & &
\end{tabular}

Table 10: Decomposition of Manufacturing TFP Growth by Plant Type (excluding computer-related industries)

\begin{tabular}{|l|c|c|c|}
\hline \multirow{2}{*}{ Export Status } & Reallocation Effect & Own-Productivity Effect & Overall \\
\cline { 2 - 4 }$\quad$ Stopper (1,0) & -0.0040 & -0.0005 & -0.0045 \\
Throughout $(1,1)$ & 0.0112 & 0.0039 & 0.0150 \\
Starter (0,1) & 0.0046 & 0.0014 & 0.0060 \\
Neither (0,0) & -0.0048 & 0.0015 & -0.0034 \\
All & 0.0070 & 0.0062 & 0.0132 \\
\hline \multicolumn{3}{|c|}{} \\
\hline Stopper (1,0) & $-30.3 \%$ & $-3.5 \%$ & $-33.8 \%$ \\
Throughout $(1,1)$ & $84.5 \%$ & $29.4 \%$ & $113.9 \%$ \\
Starter $(0,1)$ & $35.2 \%$ & $10.2 \%$ & $45.4 \%$ \\
Neither (0,0) & $-36.7 \%$ & $11.1 \%$ & $-25.5 \%$ \\
All & & $47.3 \%$ & $100.0 \%$ \\
\hline
\end{tabular}

Table 11: Decomposition of Manufacturing TFP Growth (Industry Level) (all industries)

\begin{tabular}{|l|c|c|c|}
\hline \multirow{2}{*}{} & Reallocation Effect & Own-Productivity Effect & Overall \\
\cline { 2 - 4 } & 0.0032 & Growth Rates & 0.0110 \\
\hline All & $22.5 \%$ & $\begin{array}{c}\text { \% of Total Growth Rate } \\
77.5 \%\end{array}$ & $100.0 \%$ \\
\hline All & \multicolumn{2}{|c|}{} & \\
\hline
\end{tabular}


Table 12: The Contribution of Exports to Reallocation and TFP Growth

\begin{tabular}{|c|c|c|c|c|c|}
\hline \multirow[b]{2}{*}{ Export Status } & \multicolumn{2}{|c|}{ Reallocation Effect } & \multicolumn{2}{|c|}{ Own-Productivity Effect } & \multirow[t]{2}{*}{ Overall } \\
\hline & \multicolumn{4}{|c|}{ Growth Rates } & \\
\hline Stopper $(1,0)$ & 0.0049 & -0.0090 & -0.0001 & -0.0001 & -0.0044 \\
\hline Throughout $(1,1)$ & 0.0037 & 0.0086 & 0.0048 & 0.0007 & 0.0178 \\
\hline Starter $(0,1)$ & -0.0066 & 0.0111 & 0.0013 & 0.0001 & 0.0059 \\
\hline Neither $(0,0)$ & -0.0067 & 0.0000 & 0.0016 & 0.0000 & -0.0051 \\
\hline All & -0.0048 & 0.0107 & 0.0076 & 0.0007 & 0.0142 \\
\hline & \multicolumn{5}{|c|}{$\begin{array}{l}\% \text { of Total } \\
\text { Growth Rate }\end{array}$} \\
\hline Stopper $(1,0)$ & $34.3 \%$ & $-63.3 \%$ & $-0.8 \%$ & $-1.0 \%$ & $-30.7 \%$ \\
\hline Throughout $(1,1)$ & $26.0 \%$ & $60.9 \%$ & $33.8 \%$ & $4.9 \%$ & $125.6 \%$ \\
\hline Starter $(0,1)$ & $-46.6 \%$ & $77.9 \%$ & $9.3 \%$ & $0.7 \%$ & $41.3 \%$ \\
\hline Neither $(0,0)$ & $-47.4 \%$ & $0.0 \%$ & $11.2 \%$ & $0.0 \%$ & $-36.1 \%$ \\
\hline All & $-33.6 \%$ & $75.5 \%$ & $53.5 \%$ & $4.6 \%$ & $100.0 \%$ \\
\hline
\end{tabular}

Table 13: Shutting Down the Export Sector - A Counterfactual

\begin{tabular}{|l|c|c|c|}
\hline \multirow{2}{*}{ Export Status } & Reallocation Effect & Own-Productivity Effect & Overall \\
\cline { 2 - 4 } Stopper (1,0) & 0.0057 & -0.0001 & 0.0056 \\
Throughout $(1,1)$ & 0.0092 & 0.0051 & 0.0143 \\
Starter (0,1) & -0.0064 & 0.0014 & -0.0050 \\
Neither (0,0) & -0.0035 & 0.0017 & -0.0018 \\
All & $0.0050(84.7 \%)$ & $0.0081(98.7 \%)$ & $0.0131(92.2 \%)$ \\
\hline & & & \\
& & & \\
\hline Stopper (1,0) & $43.4 \%$ & $38.8 \%$ & $42.5 \%$ \\
Throughout (1,1) & $70.3 \%$ & $10.8 \%$ & $109.1 \%$ \\
Starter (0,1) & $-48.7 \%$ & $13.0 \%$ & $-37.9 \%$ \\
Neither (0,0) & $-26.7 \%$ & $61.6 \%$ & $-13.7 \%$ \\
All & $38.4 \%$ & & $100.0 \%$ \\
\hline
\end{tabular}

This table contains a decomposition of productivity under the assumptions that there were no exports during the period and plant TFP and domestic shipments trajectories remain unchanged. Numbers in parentheses represent the ratio of the non-export growth component to the observed growth component with exports. 
Table 14: Exporting and Importing Industries

\begin{tabular}{|c|c|c|c|}
\hline \multirow[b]{2}{*}{ Industry Type } & Reallocation Effect & Own-Productivity Effect & Overall \\
\hline & \multicolumn{3}{|c|}{ Growth Rates } \\
\hline Trade Intensive & 0.0068 & 0.0006 & 0.0074 \\
\hline Export Intensive & 0.0082 & 0.0035 & 0.0117 \\
\hline Import Intensive & -0.0006 & 0.0015 & 0.0010 \\
\hline Non-Tradable & -0.0039 & -0.0001 & -0.0040 \\
\hline Other & -0.0046 & 0.0027 & -0.0019 \\
\hline All & 0.0059 & 0.0082 & 0.0142 \\
\hline \multicolumn{4}{|c|}{$\%$ of Total Growth Rate } \\
\hline Trade Intensive & $47.9 \%$ & $4.6 \%$ & $52.5 \%$ \\
\hline Export Intensive & $58.1 \%$ & $24.7 \%$ & $82.8 \%$ \\
\hline Import Intensive & $-3.9 \%$ & $10.8 \%$ & $6.8 \%$ \\
\hline Non-Tradable & $-27.8 \%$ & $-0.7 \%$ & $-28.6 \%$ \\
\hline Other & $-32.5 \%$ & $18.9 \%$ & $-13.6 \%$ \\
\hline All & $41.8 \%$ & $58.2 \%$ & $100.0 \%$ \\
\hline
\end{tabular}

Table 15: Exporters and Industry Types

\begin{tabular}{|clrrr|}
\hline Industry Type & \multicolumn{1}{c}{ Plant Type } & Reallocation & $\underline{\text { Own }}$ & Total \\
\cline { 2 - 5 } Trade Intensive & Stopper $(1,0)$ & $2.5 \%$ & $0.6 \%$ & $3.1 \%$ \\
& Throughout $(1,1)$ & $28.5 \%$ & $0.4 \%$ & $28.9 \%$ \\
& Starter $(0,1)$ & $6.9 \%$ & $1.6 \%$ & $8.5 \%$ \\
& Neither $(0,0)$ & $9.9 \%$ & $1.9 \%$ & $11.8 \%$ \\
& Stopper $(1,0)$ & $-8.2 \%$ & $-2.3 \%$ & $-10.5 \%$ \\
& Throughout $(1,1)$ & $58.9 \%$ & $22.8 \%$ & $81.7 \%$ \\
& Starter $(0,1)$ & $4.7 \%$ & $1.6 \%$ & $6.4 \%$ \\
& Neither $(0,0)$ & $2.5 \%$ & $2.4 \%$ & $5.0 \%$ \\
Import Intensive & Stopper $(1,0)$ & $-7.6 \%$ & $1.0 \%$ & $-6.6 \%$ \\
& Throughout $(1,1)$ & $0.3 \%$ & $4.7 \%$ & $4.9 \%$ \\
& Starter $(0,1)$ & $10.5 \%$ & $1.7 \%$ & $12.2 \%$ \\
Non-Tradable & Neither $(0,0)$ & $-7.1 \%$ & $3.4 \%$ & $-3.7 \%$ \\
& Stopper $(1,0)$ & $-1.7 \%$ & $-0.5 \%$ & $-2.2 \%$ \\
& Throughout $(1,1)$ & $0.1 \%$ & $0.5 \%$ & $0.6 \%$ \\
& Starter $(0,1)$ & $1.2 \%$ & $0.7 \%$ & $1.9 \%$ \\
& Neither $(0,0)$ & $-27.4 \%$ & $-1.5 \%$ & $-28.8 \%$ \\
Other & Stopper $(1,0)$ & $-14.0 \%$ & $-0.6 \%$ & $-14.6 \%$ \\
& Throughout $(1,1)$ & $-0.9 \%$ & $10.2 \%$ & $9.4 \%$ \\
& Starter $(0,1)$ & $8.1 \%$ & $4.3 \%$ & $12.4 \%$ \\
& Neither $(0,0)$ & $-25.3 \%$ & $4.9 \%$ & $-20.4 \%$ \\
\hline
\end{tabular}

